\title{
Electrochemical Behavior and Voltammetric Determination of Albendazole Using Carbon Paste Electrode
}

\author{
Gaber. A.M. Mersal ${ }^{1, *}$, Salman S. Alharthi ${ }^{1}$ and Nouf. A.S. Al Maliki ${ }^{1}$, Sayed. I.M. Zayed ${ }^{2}$ \\ ${ }^{1}$ Department of Chemistry, College of Science, Taif University, P.O. Box 11099, Taif 21944, Saudi \\ Arabia \\ ${ }^{2}$ Faculty of Industrial Education, Beni-Suef University, Beni-Suef, Egypt \\ *E-mail: gamersal@tu.edu.sa
}

doi: $10.20964 / 2021.06 .25$

Received: 8 February 2021 / Accepted: 30 March 2021 / Published: 30 April 2021

\begin{abstract}
Cyclic voltammetry (CV) and differential pulse voltammetry (DPV) techniques were used to study the electrochemical activity of albendazole (ABZ) in carbon paste electrodes (CPE). Using Britton-Robinson (BR) buffer ( $\mathrm{pH} 4.01)$ ABZ, only one oxidation peak (Ep $=0.873 \mathrm{~V}$ ) was observed, suggesting that the irreversible oxidation mechanism and this process are regulated by adsorption. The various experimental parameters for oxidation of $\mathrm{ABZ}$ have been customized. The oxidation peak current is proportional to the concentrations of $\mathrm{ABZ}$ within the range from 0.0265 to $0.1855 \mu \mathrm{g} / \mathrm{ml}$ under optimum conditions. The limits of detection and quantification obtained are 0.015 and $0.048 \mu \mathrm{g} / \mathrm{mL}$. This approach was used in drug products and human urine samples for the voltammetric detection of ABZ.
\end{abstract}

Keywords: Albendazole (ABZ), DPV, CPE, pharmaceutical formulations, urine.

\section{$\underline{\text { FULL TEXT }}$}

(C) 2021 The Authors. Published by ESG (www.electrochemsci.org). This article is an open access article distributed under the terms and conditions of the Creative Commons Attribution license (http://creativecommons.org/licenses/by/4.0/). 